\title{
Ranges and Diversity of Soybean Fungal Diseases in North America
}

\author{
X. B. Yang and F. Feng
}

Department of Plant Pathology, Iowa State University, Ames 50011.

Current address of F. Feng: Biological Science Department, National Science Foundation of China, Beijing. Accepted for publication 1 May 2001.

\begin{abstract}
Yang, X. B., and Feng, F. 2001. Ranges and diversity of soybean fungal diseases in North America. Phytopathology 91:769-775.

Introduced in 1765, soybean is the second largest crop in North America and is grown over a diverse agroecosystem that covers a geographic area of 2,300 km in north-south (N-S) and 2,400 km in east-west (E-W) directions (latitude $28^{\circ} 33$ to $48^{\circ} 33^{\prime} \mathrm{N}$, longitude $74^{\circ} \mathrm{W}$ to $103^{\circ} 02^{\prime} \mathrm{W}$ ). The diversity and the distribution ranges of soybean fungal diseases in this agroecosystem were examined and several geographic patterns were identified. Disease diversity measured by the number of

diseases per latitudinal breadth had a gradient that decreased as latitude increased. Diseases with ranges centered at higher latitudes had greater geographic ranges in the N-S direction. Disease diversity measured by number of diseases per longitudinal breadth decreased from E-W. Significant linear relationships between disease diversity and planting area were found. A region centered around the Delta Area (approximately 36 to $39^{\circ} \mathrm{N}$ and 88 to $91^{\circ} \mathrm{W}$ ), which is a transition area of three rainfall regime regions of the continent and is an area of confluence of the Mississippi, Missouri, and Ohio rivers, had the highest disease diversity in this agroecosystem.
\end{abstract}

Predicting the occurrence of and assessing the damage from plant pests over large geographic scales has been of interest for decades. Recent developments in agricultural systems $(9,13,34)$ have challenged us to predict pest risk on a large scale (38-41). Prediction of the occurrence and associated risk of agricultural pests on a large scale is an important topic in modern agricultural science, such as risk assessment of exotic pests for international seed trade, risk assessment in biotechnology application (35), assessment of new emerging pests for sustainable agriculture, benefit/risk assessment for biological control $(15,35)$, and assessment of diseases associated with global warming (19). Furthermore, quantification of disease occurrence on a large scale is fundamental for regional yield loss assessment. The idea of macroscale risk assessment has been raised by Colwell (8) for medical epidemiology.

The current approach to macroscale pest risk assessment relies on the traditional methodologies of collecting data by manipulated small plot tests, developing mechanistic models, and conducting computer simulation using weather data as inputs. This approach relies on a large quantity of point-specific data to discern empirical patterns of pest occurrence. For example, the risk assessment for exotic diseases is predicted by extrapolating information from manipulated small-scale experiments (38). This is expensive to do on a case-by-case basis and is often not repeatable.

One alternative approach is to study the relationship between pests and environment that characterizes patterns of distribution ranges and abundance of the pests on a large scale. Large-scale distribution patterns of plant or animal species have been found in ecosystems (6,7). For instance, Rapoport (23) reported that tree species whose ranges are centered at increasingly high latitude tend to be distributed over an increasingly wide range of latitude. The statistical and mathematical relationship between species diversity and abundance has been studied $(5,14)$; however, it is unknown if large-scale statistical patterns of pest occurrence are

Corresponding author: X. B. Yang; E-mail address: xbyang@iastate.edu

Publication no. P-2001-0608-01R

(c) 2001 The American Phytopathological Society present in agroecosystems that have been extensively modified in comparison with undisturbed ecosystems. If patterns exist, it would be useful to assess the risk of agricultural pests on a large scale in an agroecosystem.

In this study, we characterized the geographic patterns of agricultural pests by using soybean fungal diseases in North America as a model. The soybean (Glycine max L. Merr.) agroecosystem has diverse geographic features in North America and is the largest soybean production area in the world. Originally from China, soybean is second only to corn as the largest row crop in the United States (18). It was introduced into North America from China, with the first reported cultivation in Georgia in 1765 (16). Large-scale commercial production of soybean in the United States and Canada started early in the 20th century and was centered in Illinois and Iowa (17). Now, soybean is widely grown from southern Texas $\left(28^{\circ} 33^{\prime} \mathrm{N}\right)$ to nothern North Dakota $\left(48^{\circ} 33^{\prime} \mathrm{N}\right)$ and from the east coast $\left(74^{\circ} \mathrm{W}\right)$ to west Texas $\left(103^{\circ} 02^{\prime} \mathrm{W}\right)$ (Fig. 1). In the regions where soybean is grown, density of soybean planting varies with the highest hectarage per unit area in the north central region of the United States. A total of 44 soybean fungal diseases had been documented prior to 1996, of which 33 occur in North America $(22,26)$. The occurrence of individual diseases in this agroecosystem is well studied and documented $(1,3,12,22,26,27)$. Organized assessments on the occurrence and yield losses caused by individual diseases have been carried out for decades on a regional scale $(10,37)$.

In this large agroecosystem, there are diverse climates with annual rainfall ranging from $1,500 \mathrm{~mm}$ in coast areas to $600 \mathrm{~mm}$ in western soybean-grown areas. The minimum winter (January) temperatures range from below $40^{\circ} \mathrm{C}$ in the north to above $0^{\circ} \mathrm{C}$ in Florida. Continentality, an index reflecting seasonal range of temperatures, increases from 22 in Louisiana coast to 55 in northern North Dakota. Because certain fungi require certain ranges of temperatures and moisture for optimum growth during growing seasons, the probability of a fungus to proliferate should vary in different regions in this agroecosystem. Similarly, the diverse winter temperatures in different regions should affect survival differently for different fungi. Therefore, different fungi may fit to different climate regions in this agroecosystem, resulting in a diverse distribution pattern of soybean diseases. 
We hypothesize that distribution patterns of fungal diseases exist in the soybean agroecosystem because of the following three ecological principles. First, there are diverse climates in the soybean production areas of North America, from humid continental to humid subtropic and subtropic as discussed previously. Second, climate diversity should affect disease diversity, because the occurrence of different diseases requires different climatic conditions. Third, the planting areas, which differ from north to south, may affect disease diversity similar to the species-area relationship (number of species increases with area) found in other ecosystems (24). This hypothesis is supported by numerous documents which show that, in the United States, the profiles of economically important diseases differ from north to south. For example, root diseases are major production problems in the north (10), whereas foliar diseases are important in the south (37). Even within a state, geographic differences in disease occurrence have been observed by Eathington et al. (11).

On a large scale, disease diversity and disease range are two basic variables that can be used to quantitatively describe the geographic distribution and importance of plant diseases in an agroecosystem. In this study, a documented disease range is defined as the maximum distance between two locations in the north-south $(\mathrm{N}-\mathrm{S})$ or east-west $(\mathrm{E}-\mathrm{W})$ direction where occurrence of a disease has been observed and documented in scientific journals. Disease diversity is a measure of the number of diseases found in a given area. Specifically, we examined geographic relationships between disease range and latitude, disease diversity and latitude or longitude, and disease diversity and soybean planting area.

\section{MATERIALS AND METHODS}

Soybean and soybean disease distribution. In this study, we examined host (soybean) distribution data before collecting and analyzing data on disease distribution, an approach that was used previously by Strong (31), Strong et al. (33), and Strong and Levin (32). The distribution of soybean in North America, east of the Rocky Mountains (the United States and Canada), was analyzed in relation to disease ranges. In the United States, census data from the 1996 soybean planting area (hectares) of individual counties were made available by the U.S. Department of Agriculture in a

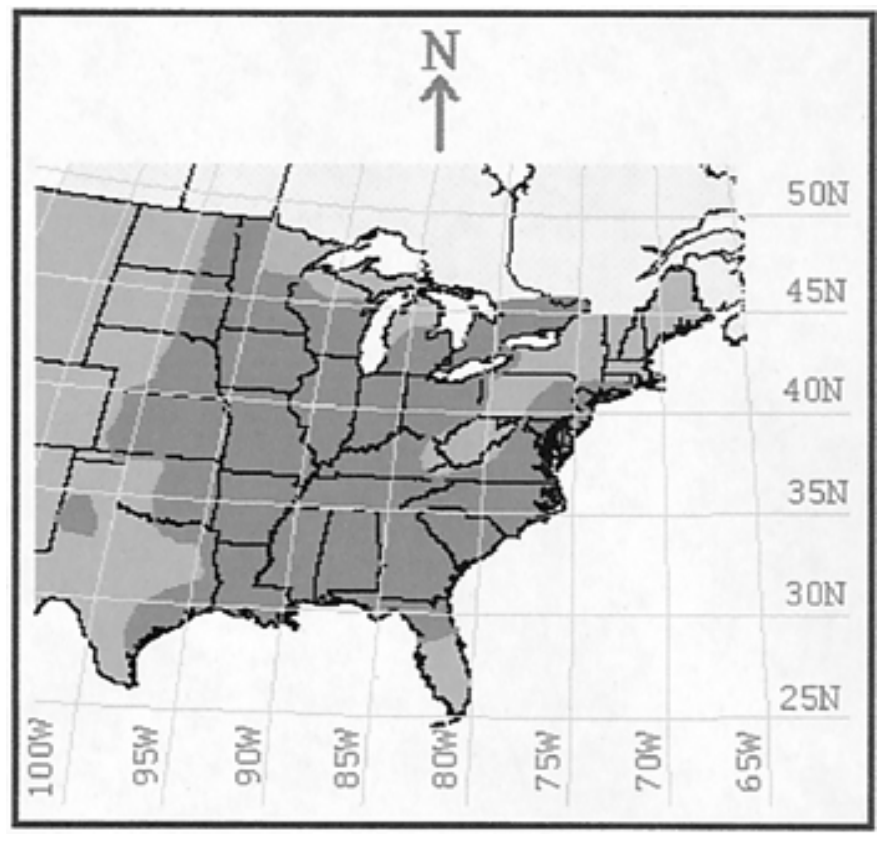

Fig. 1. Soybean production area (shaded portion) east of the Rocky Mountains in the United States and Canada. The unshaded area is part of Canada, and light-shaded area is east of the Rocky Mountains in the United States. Areas of heavy shade are soybean production areas. database maintained by Cornell University. The database contains soybean planting information of U.S. counties that cover a geographic range from $28^{\circ} 33^{\prime}$ to $48^{\circ} 33^{\prime} \mathrm{N}$ in the N-S direction and $74^{\circ}$ to $103^{\circ} 02^{\prime} \mathrm{W}$ in the $\mathrm{E}-\mathrm{W}$ direction. In Canada, soybeans are grown in the Provinces of Ontario and Quebec, with $95 \%$ of the planting areas in southern and central Ontario (below $45^{\circ} \mathrm{N}$ ). The northern area for soybean production is southern Quebec. Data from the 1996 soybean planting areas in individual counties in Ontario and Quebec were obtained from Agriculture Canada. Using median latitudes or median longitudes of counties, we sorted and summed data of planting areas by latitudinal or longitudinal breadth to obtain hectares per latitude or longitude. The planting areas were plotted against latitude or longitude to examine the geographic distribution.

The occurrence of individual diseases in different geographic regions of North America has been monitored and documented over several decades. To determine the disease range, we first determined the occurrence of individual soybean diseases in the different geographic regions in the N-S and E-W directions. The occurrence data of individual diseases were obtained in two steps: (i) from previously compiled references $(1,3,4,12,22,26,27)$ and (ii) by searching the original references of individual diseases to confirm accuracy and to update the occurrence information through 1996. Misidentifications of a disease in a given region, such as the erroneous report of soybean rust (Phakopsora pachyrhizi Sydow) in Georgia in the 1930s, were not included in the analysis. The latitude and longitude of a disease occurrence were determined (Table 1). The presence or absence of individual diseases in each latitudinal or longitudinal breadth was used to describe the distribution of the diseases in this agroecosystem.

Disease range analysis. The occurrence of different diseases requires different environmental conditions, and the varying geographic features of this agroecosystem may have resulted in variations in the distribution ranges. A disease range is defined as the maximum spatial distance between two locations where occurrence of a disease has been documented in the N-S or E-W direction. The differences in latitudes and longitudes between the two locations were calculated and converted to distances in kilometers using standardized conversion factors. We grouped the diseases by their distribution ranges at $500-\mathrm{km}$ increments in the N-S or E-W directions to examine differences and commonality before a quantitative analysis was conducted. The second component in our disease range analysis was to determine how the range of a disease is affected by the geographic environment. One general finding in macroecology is that species centered at higher latitudes tend to distribute over greater geographic ranges than species centered at lower latitudes (23), a finding called the "Rapoport rule" (28). For our analysis of soybean diseases, we arbitrarily defined the center (centroid) of a disease range as the median latitude of the distribution, a method reported previously $(6,20,21)$. The centroids of individual disease ranges (latitude) were calculated and plotted as an independent variable against the disease ranges (kilometers) before regression analysis was conducted between the two variables.

Because the variation of climate variables in the E-W direction differs from that in the N-S direction, and because such a difference may affect the disease distributions, some diseases may have greater ranges of distribution in the E-W direction than in the $\mathrm{N}-\mathrm{S}$ direction or vice versa, depending on which climate variables are limiting factors to the occurrence of these diseases. For a given region, when the ranges of diseases in the E-W direction are plotted against ranges in the N-S direction, the resulting pattern of the scatter plot is an indication of geographic effects on disease distribution. If latitudinal effects on individual diseases are equivalent to longitudinal effects, the disease ranges in each direction are expected to be similar. Therefore, the points in the range plot would be closely scattered along a 1:1 line.

Disease diversity. Disease diversity is measured by the number of diseases in a latitudinal or longitudinal breadth. Effects of the following two variables on diversity were determined: (i) latitude 
or longitude (geographic dimension), and (ii) planting area (hectares in latitudinal or longitudinal breadth). We first quantified the diversity by counting the number of soybean fungal diseases in each latitudinal or longitudinal breadth over this soybean agroecosystem. The number of diseases per latitudinal or longitudinal breadth was plotted against the latitude or longitude to examine the patterns of disease diversity in this agroecosystem. Regression analyses were conducted between latitude and disease diversity or between longitude and disease diversity.

Two analyses were conducted to determine if soybean planting area affects the diversity of soybean fungal diseases. In the first method, both soybean hectarage and the number of diseases were plotted against latitude to examine the similarity of trends. A similarity between the two curves would indicate an inherent correlation. In the second method, the number of diseases per latitudinal breadth was plotted against soybean hectarage in hectares per latitudinal breadth, which was transferred to logarithmic units, and regression analysis was performed to examine the relationship between disease diversity and soybean hectarage per latitudinal breadth. The same analyses were performed for the relationship in the longitudinal dimension.

\section{RESULTS}

Soybean hectares and disease distribution. There was approximately 28.84 million hectares of soybean planted in North

TABLE 1. Ranges of soybean fungal diseases as measured by latitude or longitude and calculated distances in area east of Rocky Mountains in North America soybean production region before $1996^{\mathrm{a}}$

\begin{tabular}{|c|c|c|c|c|}
\hline \multirow[b]{2}{*}{ Disease } & \multicolumn{2}{|c|}{ Distance $(\mathrm{km})$} & \multicolumn{2}{|c|}{ Disease ranges } \\
\hline & $\mathrm{N}-\mathrm{S}$ & E-W & Latitude (N) & Longitude \\
\hline (1) & 0 & & $3^{\prime}-48^{\circ} 33^{\prime}$ & $75^{\circ} 5$ \\
\hline Downy mildew & 220 & & $28^{\circ} 33^{\prime}-48^{\circ} 33^{\prime}$ & $03^{\circ} 2^{\prime}$ \\
\hline Frogeye leaf spot & 077.92 & $1,879.04$ & $29^{\circ} 50^{\prime}-48^{\circ} 33^{\prime}$ & $75^{\circ} 5^{\prime}-97^{\circ} 40^{\prime}$ \\
\hline Pod and stem blight & 2,220 & $2,458.72$ & $28^{\circ} 33^{\prime}-48^{\circ} 33^{\prime}$ & $74^{\circ} 0^{\prime}-$ \\
\hline Purple seed stain & $1,770.45$ & $2,500.76$ & $28^{\circ} 33^{\prime}-44^{\circ} 30^{\prime}$ & $74^{\circ} 0^{\prime}$ \\
\hline Sclerotinia stem rot & $1,381.95$ & $2,117.65$ & $36^{\circ} 6^{\prime}-48^{\circ} 33^{\prime}$ & $75^{\circ} 13^{\prime}-101^{\circ} 23^{\prime}$ \\
\hline Alternaria leaf spot &, 077.92 & & $'-48^{\circ} 33^{\prime}$ & \\
\hline Brown & 2,220 & $2,384.96$ & $28^{\circ} 33^{\prime}-48^{\circ} 33^{\prime}$ & $74^{\circ} 0^{\prime}-103^{\circ} 2^{\prime}$ \\
\hline Brov & 982.46 & & $-48^{\circ} 33^{\prime}$ & $1^{\circ} 23^{\prime}$ \\
\hline Charcoal rot & 2,220 & 2,36 & $28^{\circ} 33^{\prime}-48^{\circ} 33^{\prime}$ & $75^{\circ} 5^{\prime}-$ \\
\hline \multicolumn{5}{|l|}{ Fusarium pod } \\
\hline & & & $-48^{\circ} 33^{\prime}$ & $76^{\circ} 17$ \\
\hline Fusar & $1,982.46$ & $2,179.48$ & $30^{\circ} 41^{\prime}-48^{\circ} 33^{\prime}$ & $1^{\circ} 23^{\prime}$ \\
\hline & & & $9^{\prime}-42^{\circ} 3^{\prime}$ & $3^{\circ} 59^{\prime}$ \\
\hline & 2,220 & 2,36 & $'-48^{\circ} 33^{\prime}$ & $75^{\circ} 5^{\prime}-$ \\
\hline Phyt & $1,623.93$ & $2,239.41$ & $5^{\prime}-48^{\circ} 33^{\prime}$ & $1^{\circ} 23^{\prime}$ \\
\hline Pythiun & $2,033.52$ & 2,10 & $-48^{\circ} 33^{\prime}$ & $1^{\circ} 23^{\prime}$ \\
\hline Rhizoc & 687.09 & 1,09 & $\prime-34^{\circ} 44^{\prime}$ & $90^{\circ} 42^{\prime}-103^{\circ} 2^{\prime}$ \\
\hline Rhiz & $2,005.77$ & 2,16 & $\prime^{\prime}-48^{\circ} 33^{\prime}$ & $75^{\circ} 13^{\prime}-$ \\
\hline & 2,220 & 2,26 & $\prime-48^{\circ} 33^{\prime}$ & $75^{\circ} 59^{\prime}-103^{\circ} 2^{\prime}$ \\
\hline ight & & & $-42^{\circ} 3^{\prime}$ & $75^{\circ} 59^{\prime}$ \\
\hline & $2,033.52$ & $1,598.33$ & $-48^{\circ} 33^{\prime}$ & $75^{\circ} 13^{\prime}-c$ \\
\hline & & & $-38^{\circ} 18^{\prime}$ & $3^{\circ} 2^{\prime}$ \\
\hline & $1,750.47$ & 969.37 & $29^{\circ} 50^{\prime}-45^{\circ} 36^{\prime}$ & $82^{\circ} 29^{\prime}-93^{\circ} 59^{\prime}$ \\
\hline & & $1,303.84$ & $30^{\circ} 14^{\prime}-43^{\circ} 29^{\prime}$ & $81^{\circ} 14^{\prime}-96^{\circ} 36^{\prime}$ \\
\hline & $1,094.46$ & $1,828.27$ & $32^{\circ} 37^{\prime}-42^{\circ} 30^{\prime}$ & $75^{\circ} 59^{\prime}-97^{\circ} 40^{\prime}$ \\
\hline Choanephora leaf s & 352.98 & 291.79 & $29^{\circ} 50^{\prime}-33^{\circ} 1^{\prime}$ & $90^{\circ} 42^{\prime}-93^{\circ} 59^{\prime}$ \\
\hline \multicolumn{5}{|l|}{ Leptosphaerulina } \\
\hline & 499.5 & 1,71 & & ${ }^{\circ} 40^{\prime}$ \\
\hline Myco & 599.4 & 318 & $37^{\circ} 1^{\prime}-42^{\circ} 30^{\prime}$ & $87^{\circ} 35^{\prime}-91^{\circ} 26^{\prime}$ \\
\hline Neoc & 523.92 & 632.38 & $30^{\circ} 17^{\prime}-35^{\circ} 0^{\prime}$ & $81^{\circ} 14^{\prime}-88^{\circ} 26^{\prime}$ \\
\hline Powdery mildew & $1,718.28$ & $1,732.90$ & $30^{\circ} 14^{\prime}-45^{\circ} 43^{\prime}$ & $75^{\circ} 59-96^{\circ} 37$ \\
\hline & $1,033.41$ & $1,557.18$ & $29^{\circ} 50^{\prime}-39^{\circ} 8^{\prime}$ & $75^{\circ} 59^{\prime}-93^{\circ} 59^{\prime}$ \\
\hline Sudden death syndrome & 1,113 & 720 & $33^{\circ} 33^{\prime}-43^{\circ} 29^{\prime}$ & $84^{\circ} 36^{\prime}-93^{\circ} 00^{\prime}$ \\
\hline
\end{tabular}

a The data are based on published reports until 1996. The north-south (N-S) distances (kilometers) of a disease is calculated from the range of latitude using equation $\left(1^{\circ} \mathrm{N}=111 \mathrm{~km}\right)$; the east-west $(\mathrm{E}-\mathrm{W})$ distance is calculated from the range of longitude as distance $=\{111-[(111-79) / 45] \times$ latitude center $\} \times$ longitude range $\left(\mathrm{W}^{\circ}\right)$.
America in 1996 with a nonuniform distribution over this agroecosystem, which covers an area of $28^{\circ} 33^{\prime}$ to $48^{\circ} 33^{\prime} \mathrm{N}$ and $74^{\circ} 00^{\prime}$ to $103^{\circ} 02^{\prime} \mathrm{W}$ (Fig. 2). In the latitudinal range of 33 to $45^{\circ} \mathrm{N}$, soybean hectarage was greater than 0.4 million hectares per latitudinal breadth. Approximately $50 \%$ of the planted area was in a range of 39 to $43^{\circ} \mathrm{N}$, covering Iowa, Illinois, and parts of Indiana and Ohio. There was more than 2.43 million hectares per latitudinal breadth in this area. The planted area was over 3.24 million hectares per latitudinal breadth in the 40 to $42^{\circ} \mathrm{N}$ range. In the $\mathrm{E}-\mathrm{W}$ range of 83 to $97^{\circ} \mathrm{W}$, the planted area was over 0.4 million hectares per longitudinal breadth, and most of the soybeans were grown from 88 to $97^{\circ} \mathrm{W}$, which accounted for over $70 \%$ of the total planted area.

Of the 33 fungal diseases that were reported in North America by 1996, a few have been found in all areas where soybean is grown, with wide distributions and ranges. Of these reported fungal diseases, a few have broad distributions covering the entire soybean production range, such as pod and stem blight (Diaporthe sojae Lehman), whereas others have a limited distribution. Neocosmospora stem rot (Neocosmospora vasinfecta Smith) is limited to the south $\left(30^{\circ} 16^{\prime}\right.$ to $\left.35^{\circ} 00^{\prime} \mathrm{N}\right)$, with a calculated N-S range of $524 \mathrm{~km}$ and an E-W range of $508 \mathrm{~km}$. Mycoleptodiscus root rot (Mycoleptodiscus terrestris Gerd.) is distributed in a range of $37^{\circ} 00^{\prime}$ to $42^{\circ} 29^{\prime} \mathrm{N}$, with a N-S range of $599 \mathrm{~km}$ and an E-W range of $1,596 \mathrm{~km}$. Sclerotinia stem rot (Sclerotinia sclerotiorum [Lib.] $\mathrm{d}$ By.), a cool-season disease, is centered in the northern soybean production region. Southern blight $(S$. rolfsii Tu \& Kimbr) is centered in tropical and subtropical regions.
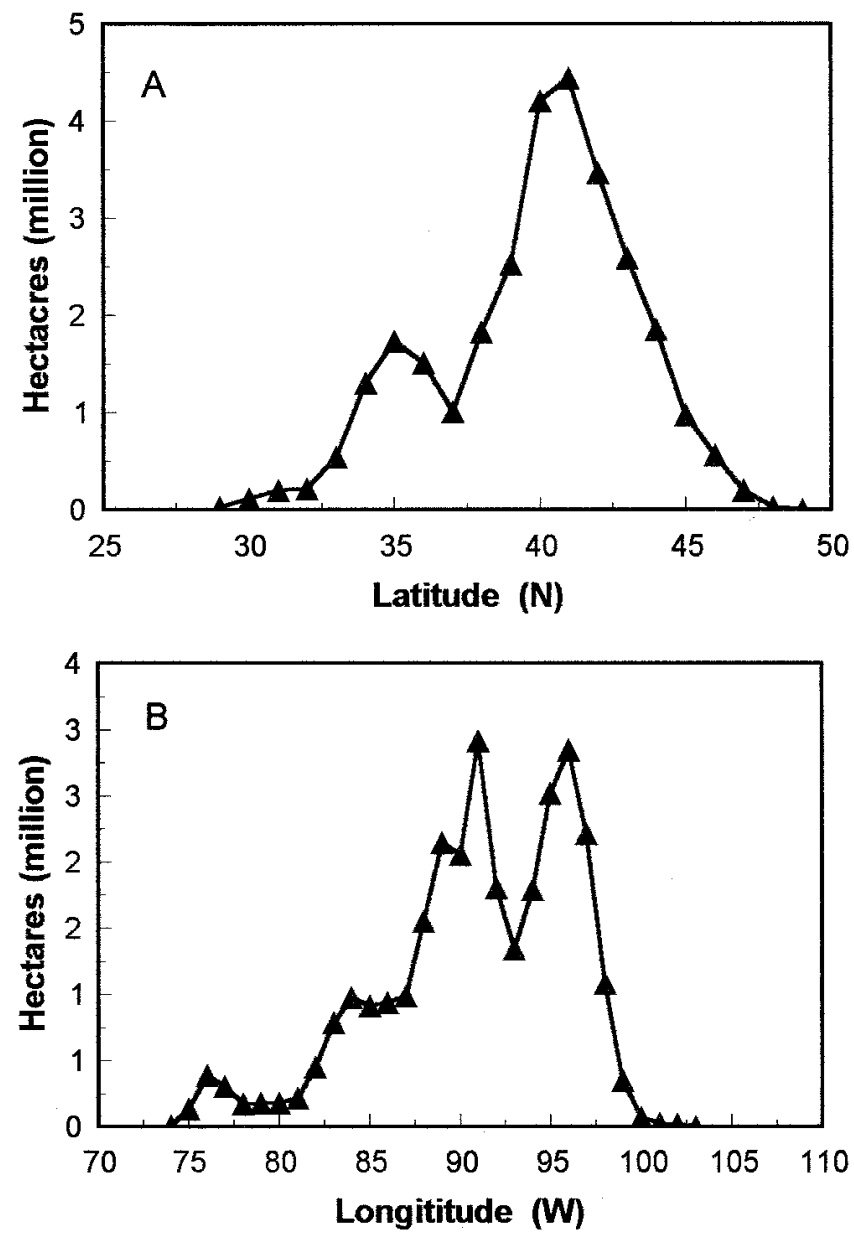

Fig. 2. Distribution of soybean hectarage east of the Rocky Mountains in the United States and Canada in A, latitudinal direction $\left(28^{\circ} 3^{\prime}\right.$ to $\left.48^{\circ} 33^{\prime} \mathrm{N}\right)$ in 1996 and $\mathbf{B}$, longitudinal direction $\left(74^{\circ}\right.$ to $\left.103^{\circ} 02^{\prime} \mathrm{W}\right)$. The data points represent hectarage per latitudinal or longitudinal breadth. 
The latitudinal centroids of the disease ranges are in an area between the latitudes of $31^{\circ} 25^{\prime}$ to $42^{\circ} 19^{\prime} \mathrm{N}$. Diseases with centroids in the higher latitudes usually have much greater ranges than diseases with centroids in low latitudes (Fig. 3). A significant linear relationship between the latitude centroid and disease range was found $\left(R^{2}=0.38 ; P<0.05\right)$; as the latitude increases, the range of a disease increases. Two diseases, Leptosphaerulina leaf spot (Leptosphaerulina trifolii) and Mycoleptodiscus root rot $(M$. terrestris), had centroids at $38^{\circ} 18^{\prime}$ and $39^{\circ} 48^{\prime} \mathrm{N}$, respectively, but had relatively small distribution ranges.

To examine if the latitude affects disease distribution differently than longitude, we plotted disease ranges in the N-S direction against ranges in the $\mathrm{E}-\mathrm{W}$ direction. There was a trend in the plot that the E-W range increased as the N-S range of a disease increased (Fig. 4), but more points scattered above the 1:1 line, with the highest departure for diseases that have smaller geographic ranges in the N-S direction than in the E-W direction, which suggests that there were more diseases with greater ranges in the E-W direction than in the N-S direction. This was further supported by results of a regression through origin that produced a slope of 1.07 , significantly greater than $1.0(P<0.0001)$.

Latitude effect on disease diversity. Latitude significantly affected disease diversity because there were more soybean fungal diseases in the south than in the north. A significant relationship between latitude and the number of diseases was found $(P<$ 0.0001 ), with the highest number of diseases between the latitudes of 36 and $38^{\circ} \mathrm{N}$ (Fig. 5A). The number of diseases increased from 16 diseases below $29^{\circ} \mathrm{N}$ to 28 at $37^{\circ} \mathrm{N}$. The lower number of diseases below $29^{\circ} \mathrm{N}$ (16 diseases) may be due to the confounding effect of the small planted area, only 30,270 ha. At $30^{\circ} \mathrm{N}$ latitude $(114,490$ ha in this breadth), there were 21 reported diseases. Twenty-eight reported diseases, by far the highest, occurred at $37^{\circ} \mathrm{N}$. The number of diseases decreased from 28 to 14 at $49^{\circ} \mathrm{N}$. In general, the disease diversity decreased toward the north. A quadratic regression equation was significant and was further improved $\left(R^{2}=0.88 ; P<0.0001\right)$ when the point in $28^{\circ} \mathrm{N}$, where only a small acreage of soybean was planted, was identified as an outliner.

Longitude effect on disease diversity. In the E-W direction, the disease diversity was generally higher in the east than in the west, with the Mississippi River valley having the highest number of diseases. The number of diseases increased from 23 at $75^{\circ} \mathrm{W}$ to 32 at $91^{\circ} \mathrm{W}$, and decreased dramatically at $94^{\circ} \mathrm{W}$ on the west side of the Mississippi River because only 12 diseases were found at $103^{\circ} \mathrm{W}$ (Fig. 5B). In the far eastern area $\left(74^{\circ} \mathrm{W}\right)$, only eight diseases were recorded, possibly because of the small planted area. In the

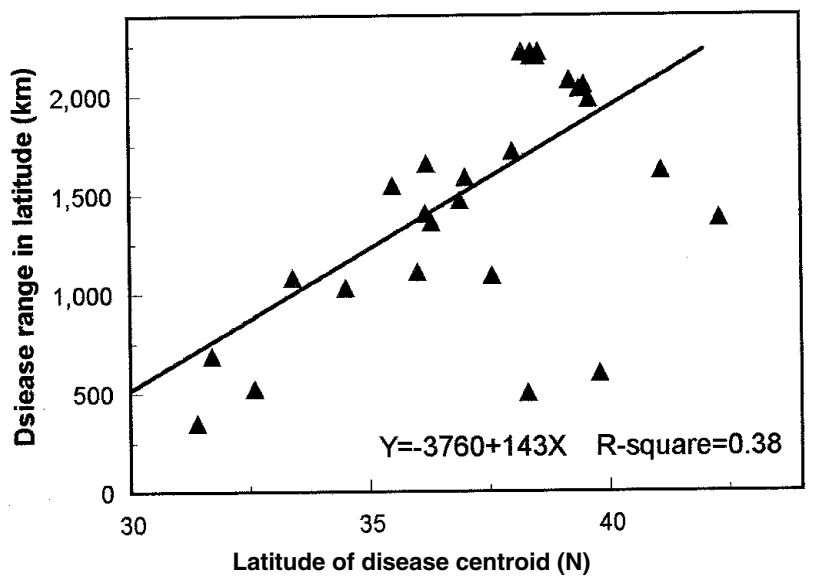

Fig. 3. The relationship between latitudinal geographic range (kilometers) of soybean fungal diseases and latitudinal centroid of soybean fungal diseases in the North American soybean agroecosystem which covers a latitudinal range of $28^{\circ} 33^{\prime}$ to $48^{\circ} 33^{\prime} \mathrm{N}$. There are hidden points in the graph because several diseases had the same centroids and ranges. longitudinal dimension, the number of diseases was highest, 30 to 32 diseases per longitudinal breadth along the Mississippi River basin $\left(87\right.$ to $\left.95^{\circ} \mathrm{W}\right)$. The diversity of disease in the $\mathrm{E}-\mathrm{W}$ direction fitted a quadratic equation with $R^{2}=0.89(P<0.0001)$.

Soybean hectarage and disease diversity. Soybean hectarage did not increase linearly as the latitude or longitude increased but follows a logarithmic relation (Fig. 2, note logarithmic transformation in hectarage). Peaks on the disease diversity-latitude curve and the hectarage-latitude curve did not match. In the latitudinal dimension, the greatest disease diversity occurred in the latitudes of 34 to $39^{\circ} \mathrm{N}$ (Fig. 5), which had relatively small soybean hectarage (1 to 1.8 million hectares per latitudinal breadth) (Fig. 2). At 40 to $42^{\circ} \mathrm{N}$ latitudes, the soybean hectarage was at its highest but the diversity of diseases was relatively low compared with latitudes of 34 to $39^{\circ} \mathrm{N}$. The number of disease tended to increase as the soybean hectarage increased in the longitudinal direction (Fig. 6). There were significant relationships between disease diversity and soybean hectarage, with $R^{2}=0.42$ for latitudinal dimension and $R^{2}=0.61$ for longitudinal dimension.

Both latitude diversity (Fig. 5A) and the longitude diversity curves (Fig. 5B) exhibited peaks. The peaks of the two curves (two dimensions) suggest an area in this agroecosystem that has the highest diversity (more than 28 diseases). This area between $\mathrm{N}-\mathrm{S} 36$ to $39^{\circ} \mathrm{N}$ and $\mathrm{E}-\mathrm{W} 88$ to $91^{\circ} \mathrm{W}$ included northeastern Arkansas, southern Illinois, southeastern Missouri, and parts of Kentucky. This area, however, did not have the highest soybean hectarage (Fig. 2), indicating that factors in addition to hectarage affected the diversity of diseases.

\section{DISCUSSION}

In this study, the distribution patterns of soybean fungal diseases in the North American agroecosystem, which covers $2,300 \mathrm{~km}$ in $\mathrm{N}-\mathrm{S}$ and 2,400 km in E-W directions, were examined and several patterns were identified. Disease diversity, measured by the number of diseases per latitudinal breadth, increased from N-S. Diseases centered at higher latitudes had wider geographic ranges in latitudinal dimension. Disease diversity was greater in the east than in the west. The number of hectares planted to soybean was significantly and positively correlated with the number of reported diseases per area. In this agroecosystem, a region centered around the Delta Area had the highest disease diversity.

We were able to develop a few regression models to describe trends. These models have a descriptive power and their predictive power is unknown. It is interesting, however, that the two

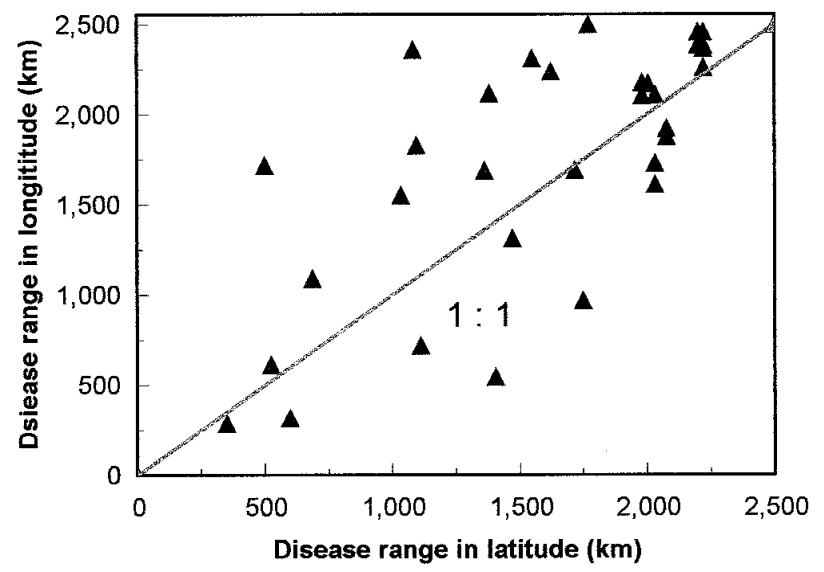

Fig. 4. Plot of disease ranges (kilometers) in two directions, north-south versus east-west, for fungal diseases in the North American soybean agroecosystem, which covers an area of $28^{\circ} 33^{\prime}$ to $48^{\circ} 33^{\prime} \mathrm{N}$ (latitude) and $74^{\circ}$ to $103^{\circ} 2^{\prime} \mathrm{W}$ (longititude). The line in the graph indicates a ratio of 1:1 for diseases that have ranges in north-south direction equal to ranges in east-west direction. 
outliners in the regression between disease centeriod and latitude may give an indication of predictive power of this regression model. One possibility of producing an outliner is that the disease has not reached its final distribution.

Further studies to quantify the relationships between climate variables and disease distributions are needed if the macroscale approach is to be used to assess the impact of environment on plant disease distribution, as the ecologists have done in assessing the impact of climate changes on species distributions (5). Similar to the macroecological studies $(5-7,31-33)$ in which species distribution data were compiled from different references, in this study, data on individual soybean diseases were compiled from published reports. The number of plant pathologists differ from region to region, which may affect the accuracy of an estimated disease range. However, the effects of the number of observers may be as important as the amount of observation time. When a disease reaches its final distribution range, the probability of the disease being discovered increases with time. With a few exceptions, the ranges of soybean diseases in this agroecosystem may have been in their final distributions, indicated by the fact that most papers that reported the first finding of soybean diseases in given regions in this agroecosystem are a decade old.

Rapoport (23) observed that tree species centered in higher latitudes tend to be distributed over a wider geographic area, and such a phenomenon has been referred to as the Rapoport rule (28). The pattern of disease ranges in the soybean agroecosystem in North America follow this rule, indicated by the positive linear relationship between disease range and centroid. Biologically, this
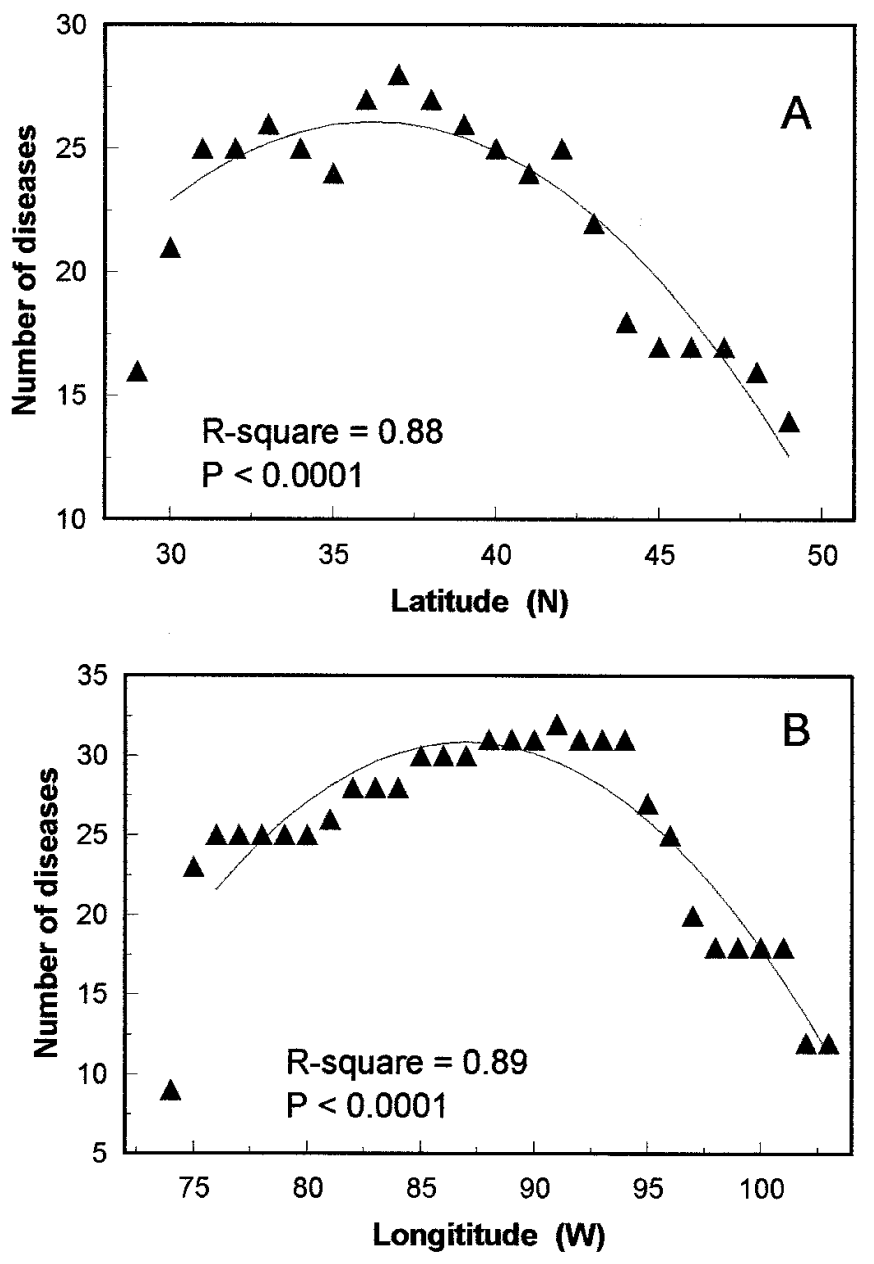

Fig. 5. Number of soybean fungal diseases shown $\mathbf{A}$, on a latitudinal gradient $28^{\circ} 33^{\prime}$ to $48^{\circ} 33^{\prime} \mathrm{N}$ and $\mathbf{B}$, on a longitudinal gradient $74^{\circ}$ to $103^{\circ} 2^{\prime} \mathrm{W}$ in the North America soybean agroecosystem. implies that the North American soybean diseases centered in the north generally have larger distribution ranges than those centered in the south.

Our results demonstrate that analogous effects on soybean disease diversity exist in the North American agroecosystem. The effects of latitude are evident in the decreased number of diseases with the increase in latitude. The latitude effects on species diversity have been found by ecologists on plant and animal species $(6,24)$. Similar patterns of species richness were also found in elevational distribution for plant species (29). In North America, the geographic variation of the two variables, temperature and moisture, which are critical to the occurrence of plant diseases, may affect the disease range. In the latitudinal dimension, temperature effects on disease occurrence are in twofolds. Latitudinal increase in winter hardness may affect fungal pathogen survival because fungi are less likely to survive well in the north than in the south, therefore, less disease diversity. The decreasing trend in the length of soybean growing seasons from south to north affects disease occurrence, especially multicycle diseases. In fact, epidemics of multicycle foliar diseases occur more frequently in the south than in the north in this agroecosystem. The amount of precipitation during a growing season decreases from south to north and from east to west (2), which should affect the ranges of diseases sensitive to moisture. For instance, development of Rhizoctonia aerial blight, a foliar disease caused by a soilborne fungus in the south, needs continuous free moisture and warm temperature for mycelium growth in the canopy. A few diseases, such as Sclerotinia stem rot and southern blight, have longitudinal
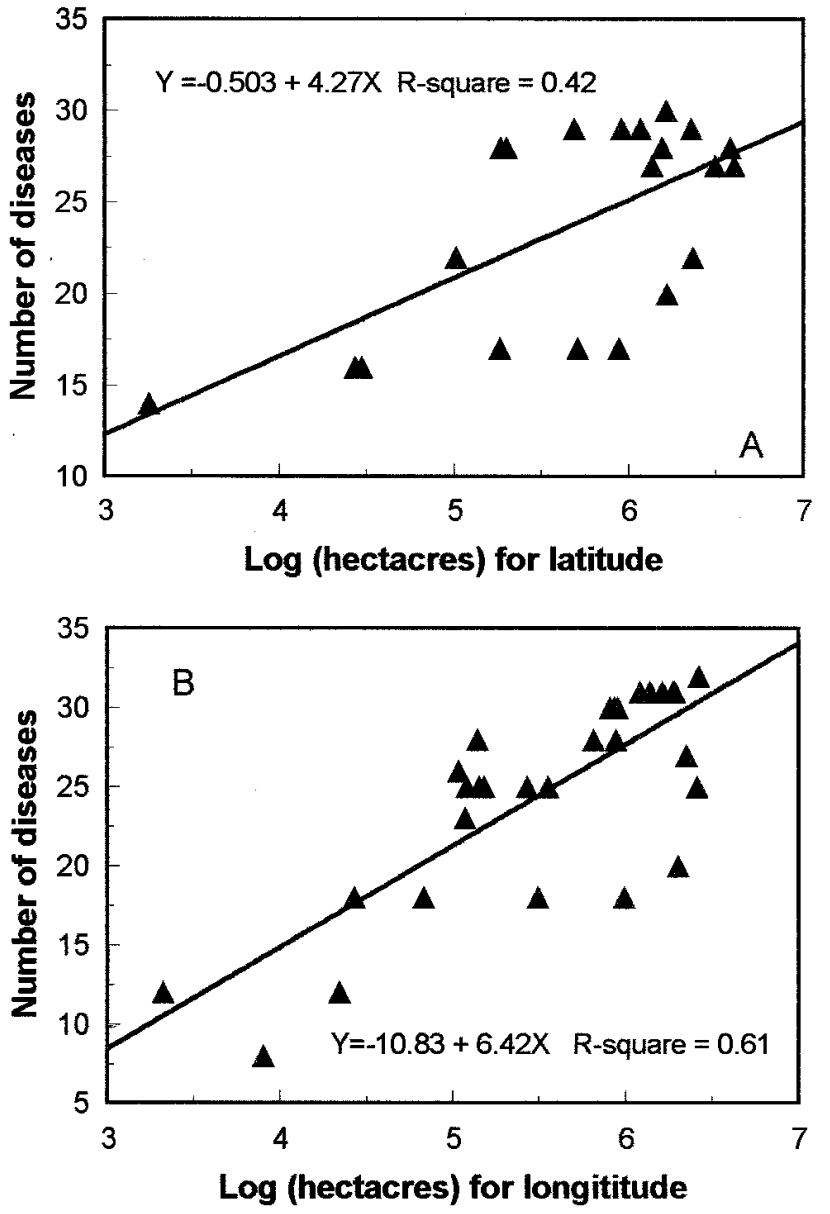

Fig. 6. Relationship between soybean hectarage and disease diversity in the North American soybean agroecosystem, which ranges from A, $28^{\circ} 33^{\prime}$ to $48^{\circ} 33^{\prime} \mathrm{N}$ (latitude) and $\mathbf{B}, 74^{\circ}$ to $103^{\circ} 2^{\prime} \mathrm{W}$ (longititude). Disease diversity was measured as the number of diseases per latitudinal or longitudinal breadth and the planting areas were sorted by latitude or longitude. 
ranges greater than latitudinal ranges, with their points scattered above the 1:1 line in Figure 4. This indicates that different variables influence the ranges between the two dimensions. The fact that some diseases have greater longitude ranges than latitude ranges indicates factors associated with latitude, such as temperature or temperature-moisture combination, may limit the ranges of these diseases. Because a distribution range of a disease is determined by several environment variables (temperature or moisture) and each variable can affect more than one phase of fungal development (winter survival or summer growth), future studies to quantitatively examine the interactive effects of these factors may provide insights to the prediction of disease distributions.

A species-area relationship exists in an agroecosystem. In ecosystems, it is generally considered that species diversity is related to the size of the area $(6,24)$. Species-area relationship has been found in a fungal parasite of British trees (32), insects of cacao (31), and insects on sugarcane (33). Strong and Levin (32) found that in England, the number of parasitic fungi in 23 tree species was significantly correlated with the distribution range of tree species. However, the effect of geographic isolation on species diversity found in this ecosystem may not exist in the soybean agroecosystem because of extensive agricultural activities. Our finding was determined by sorting soybean planting area by latitudinal and longitudinal dimensions. The wide deviation of some data points from predicted species-area curves suggested that factors other than soybean hectarage also affect the disease diversity. In an ecosystem, a species-area relationship is considered to be a result of the isolation of the ecosystem. In soybean agroecosystems, such isolation effects may not play a significant role. Without isolation, we still observed such relationships, an indication that environmental condition rather than dispersal determine distribution of plant diseases.

It is interesting that in the soybean agroecosystem, a region centered around the Delta region (approximately 36 to $39^{\circ} \mathrm{N}$ and 88 to $91^{\circ} \mathrm{W}$ ) has the highest disease diversity although soybean planting area in this region is much lower than the north central soybean production region. The Mississippi, Missouri, and Ohio rivers converge in this region. Climate in this region is more diverse than in others because this region is at the boundary of two climates, the humid continental climate in the north and humid subtropic climate in the south (30). The region is in a transition area of three rainfall regime regions, which are Ohio transition, subtropic interior, and interior (complex), of the continent. The variable climates in this area provide diverse environments for the occurrence of different diseases. Eathington et al. (11) recently summarized 13 years of disease monitoring results in Illinois that was divided into northern $\left(41^{\circ} 25^{\prime} \mathrm{N}\right.$ north), southern $\left(39^{\circ} \mathrm{N}\right.$ south), and central regions. They found that the southern region, in the fringe of the Delta Area, had the highest disease pressure measured by epidemic frequency and number of diseases. It is also interesting that soybean sudden death syndrome, a new soybean production problem in this agroecosystem, was first found in this area (25). The disease was reported in 1971 in Arkansas, first developed into a notable production problem in the Delta Area, and has expend to north central soybean production states, which accounts for $78 \%$ of U.S. soybean production (10). Similarly, when the soybean cyst nematode (Heterodera glycines Ichinohe) was introduced into the United States (36), this region served as a focus area in the spread of this pathogen to other soybean production regions. Furthermore, disease diversity may be different from species diversity because the occurrence of disease requires host, pathogen, and environment. The diversity of plant diseases, therefore, should be affected by the diversity of pathogens and by the diversity of climate in an agroecosystem. The diversity of alternative hosts may also affect the disease diversity in an area. If a center of disease diversity indeed exists, further investigation on diversities of climate and pathogens in this agroecosystem is warranted.

\section{ACKNOWLEDGMENTS}

The study was supported in part by Hatch Act and State of Iowa funds. Journal Paper No. J-17351 of the Iowa Agriculture and Home Economics Experiment Station. We thank R. B. Hartman, Y. Luo, S. Sanogo, H. Scherm, P. Sun, M. D. Uphoff, F. Workneh, and J. A. Wrather for critically reviewing the manuscript and $\mathrm{P}$. Lundeen for graphic preparation.

\section{LITERATURE CITED}

1. Athow, K. L. 1987. Fungal disease. Pages 687-727 in: Soybeans: Improvement, Production, and Uses. 2nd ed. J. R. Wilcox, ed. Monogr. 16. The American Society of Agronomy, Madison, WI.

2. Barry, R. G., and Chorley, R. J. 1992. Atmosphere, Weather, and Climate. 6th ed. Routledge, London.

3. Bebee, C. N. 1985. The Protection of Soybean, January 1980 - November 1984. U.S. Dep. Agric. Natl. Agric. Lib.

4. Bebee, C. N. 1989. The Protection of Soybean, December 1984 - February 1989. U.S. Dep. Agric. Natl. Agric. Lib.

5. Brown, J. H. 1984. On the relationship between abundance and distribution of species. Am. Nat. 124:255-279.

6. Brown, J. H. 1995. Macroecology. The University of Chicago Press, Chicago.

7. Brown, J. H., and Maurer, B. A. 1989. Macroecology: The division of food and space among species on continents. Science 243:1145-1150.

8. Colwell, R. R. 1996. Global climate and infectious disease: The cholera paradigm. Science 274:2025-2031.

9. Cook, R. J., Gabriel, G. J., Kelman, A., Tolin, S., and Vidaver, A. K. 1995. Research on plant disease and pest management is essential to sustainable agriculture. BioScience 45:354-357.

10. Doupnik, B., Jr. 1993. Soybean production and disease loss estimates for North Central United States from 1989 to 1991. Plant Dis. 77:1170-1171.

11. Eathington, S. R., Lim, S. M., Nickell, C. D., Pataky, J. K., and Esgar, R. W. 1993. Disease pressure on soybean in Illinois. Plant Dis. 77:1136-1139.

12. Farr, D. F., Bills, G. F., Chamuris, G. P., and Rossman, A. Y. 1995. Fungi on Plants and Plant Products in the United States. The American Phytopathological Society, St. Paul, MN.

13. Fulkerson, J. F. 1991. Understanding the impacts of biotechnology. Phytopathology 81:343.

14. Hanski, I., and Gyllenberg, M. 1997. Uniting two general patterns in the distribution of species. Science 275:397-400.

15. Hokkanen, H. M., and Lynch, J. M. 1996. Biological Control - Benefits and Risk. Cambridge University Press, Cambridge.

16. Hymowitz, T., and Harlan, J. R. 1983. Introduction of soybean to North America by Samuel Bowen in 1765 Glycine Max. Econ. Bot. 37:371-379.

17. International Soybean Program (INSOY). 1983. Soybean Research in China and the United States. Proc. China/USA Soybean Symp. Working Group Meet., 1st. University of Illinois Press, Urbana.

18. Iowa Agricultural Statistics Department (IASD). 1996. 1996 Iowa Agricultural Statistics Department. Des Moines, Iowa.

19. Manning, W. J., and Tiedemann, A. V. 1995. Climate change: Potential effects of increased atmospheric carbon dioxide (CO2), ozone (O3), and ultraviolet-B (UV-B) radiation on plant diseases. Environ. Pollut. 88: 219-245.

20. Maurer, B. A. 1994. Geographic Population Analysis: Tools for the Analysis of Biodiversity. Blackwell Scientific Publications, Oxford.

21. Maurer, B. A., and Villard, M. A. 1994. Population density: Geographic variation in abundance of North American birds. Res. Explor. 10:306-317.

22. McGee, D. C. 1992. Soybean Diseases: A Reference Source for Seed Technologists. The American Phytopathological Society, St. Paul, MN.

23. Rapoport, E. H. 1982. Aerography: Geographical Strategies of Species. Pergamon Press, Oxford.

24. Rosenzweig, M. L. 1995. Species Diversity in Space and Time. Cambridge University Press, Cambridge.

25. Rupe, J. C., Hirrel, M. C., and Hershman, D. E. 1989. Sudden death syndrome. Pages 84-85 in: Compendium of Soybean Diseases. 3rd ed. J. B. Sinclair and P. A. Backman, eds. The American Phytopathological Society, St. Paul, MN.

26. Sinclair, J. B., and Backman, P. A., eds. 1989. Compendium of Soybean Diseases. 3rd ed. The American Phytopathological Society, St. Paul, MN.

27. Sinclair, J. B., and Dhingra, O. D. 1975. An annotated bibliography of soybean diseases 1882-1974. International Soybean Program. Urbana, IL.

28. Stevens, G. C. 1989. The latitudinal gradient in geographical range: How so many species coexist in the tropics. Am. Nat. 133:240-256.

29. Stevens, G. C. 1992. The elevational gradient in latitudinal range: An extension of Rapoport's latitudinal rule to altitude. Am. Nat. 140:893-911.

30. Strahler, A. N. 1969. Physical Geography. 3rd ed. Wiley-Interscience, New York. 
31. Strong, D. R., Jr. 1974. Rapid asymptotic species accumulation in phytophagous insect communities: The pests of cacao. Science 185:1064-1066.

32. Strong, D. R., Jr., and Levin, D. A. 1975. Species richness of the parasitic fungi of British trees. Proc. Natl. Acad. Sci. USA 72:2116-2119.

33. Strong, D. R., Jr., McCoy, E. D., and Rey, J. R. 1977. Time and the number of herbivore species: The pests of sugarcane. Ecology 58:167-175.

34. Teng, P. S., and Savary, S. 1992. Implementing the systems approach in pest management. Agric. Syst. 40:237-264.

35. Teng, P. S., and Yang, X. B. 1993. Biological impact assessment and risk analysis in plant pathology. Annu. Rev. Phytopathol. 31:495-521.

36. United Soybean Board. 1993. Protect Your Soybean Profits: Manage Soybean Cyst Nematode. United Soybean Board, St. Louis.
37. Wrather, J. A., Chambers, A. Y., Moore, W. F., and Sciumbato, G. L. 1995. Soybean disease loss estimates for the southern United States, 1974 to 1994. Plant Dis. 79:1076-1079.

38. Yang, X. B., Dowler, W. M., and Royer, M. H. 1991. Assessing the risk and potential impact of an exotic plant disease. Plant Dis. 75:976-982.

39. Yang, X. B., and Zeng, S. M. 1992. Detecting patterns of wheat stripe rust in time and space. Phytopathology 82:571-576.

40. Zadoks, J. C., and van den Bosch, F. 1994. On spread of plant disease: A theory on foci. Annu. Rev. Phytopathol. 32:503-522.

41. Zeng, S. M. 1996. On macro-phytopathology. Pages 1-6 in: Advances of Phytopathology Research in China. (in Chinese) S.-B. Qiu, ed. Chinese Press of Science and Technology, Beijing. 